\title{
Effects of Nuclear Transfer Procedures on ES Cell Cloning Efficiency in the Mouse
}

\author{
Akiko YABUUCHI ${ }^{1)}$, Yoshiko YASUDA ${ }^{2)}$, Yoko KATO ${ }^{1)}$ and Yukio TSUNODA ${ }^{1)}$ \\ 1) Laboratory of Animal Reproduction, College of Agriculture, Kinki University, Nara 631- \\ 8505, Japan ${ }^{2}$ First Department of Anatomy, School of Medicine, Kinki University, Osaka 589- \\ 8511, Japan
}

\begin{abstract}
Enucleated oocytes receiving mouse embryonic stem (ES) cells develop into fertile young. The developmental potential to young is low, however, and the rate of postnatal death is high. We examined the effect of various nuclear transfer procedures on the in vitro and in vivo developmental potential of nuclear-transferred oocytes. The potential of oocytes receiving ES cells at M phase to develop into blastocysts after fusion by Sendai virus was high compared with that after direct injection $(67 \%$ vs. $30 \%)$. The developmental potential of oocytes receiving ES cells at the M phase is higher than that of oocytes receiving ES cells at the $\mathrm{G}_{1}$ phase (30-67\% vs. $2-5 \%$ ). Developmental ability to live young was low in all groups $(0-4 \%)$. Different activation protocols affected the potential to develop into blastocysts to a different extent (27-62\%), but did not affect the potential to develop into live young $(0-3 \%)$. The present study demonstrated that the various conditions examined did not affect the potential of nuclear-transferred oocytes receiving ES cells to develop into live young or the incidence of postnatal death.
\end{abstract}

Key words: Cell cycle, Clone, ES cells, Mouse, Nuclear transfer

(J. Reprod. Dev. 50: 263-268, 2004)

S ome of nuclear-transferred oocytes receiving mouse embryonic stem (ES) cells develop into fertile young [1-3]. Although the developmental potential of nuclear-transferred oocytes that receive ES cells is high compared with those that receive somatic cells [4], a large proportion die at various developmental stages and the rate of neonatal death is high. Recent studies have demonstrated that the epigenetic state of the ES cell genome is highly unstable and preexisting epigenetic aberrations present in ES cells are the major cause of gene dysregulation in ES-cell cloned embryos [5]. Such gene modifications might be the cause of the low rate of development into young and phenotypic abnormalities. The potential of

Accepted for publication: January 5, 2004

Correspondence: $\mathrm{Y}$. Tsunoda,

(e-mail: tsunoda@nara.kindai.ac.jp) nuclear-transferred oocytes to develop into young might be different among cell lines as ES cells with a hybrid genetic background have high developmental potential when they are transferred to oocytes or injected into tetraploid blastocysts [6]. The genetic background of ES cells is not the only factor underlying the low potential of nucleartransferred oocytes to develop into young because cell confluence and cell passages of ES cells are also important factors [7].

Another factor that influences cloning efficiency is nuclear transfer procedure. Two different procedures can be used for the nuclear transfer of mouse ES cells into oocytes from which maternal chromosomes have been removed. One is membrane fusion where whole ES cells are fused with oocytes using inactivated Sendai virus (HVJ) $[3,8,9]$. The other method is direct injection, in 
which a small volume of cytoplasm is introduced into enucleated oocytes $[1,4-6,10]$. The potential of oocytes developing into blastocysts is low [1, 4-6] using the direct injection method compared with the fusion method $[8,9]$, but development to offspring is high, especially when ES cells with the F1 genetic background are used [6]. Although Galli et al. [11] reported that there was no significant difference between microinjection and cell fusion methods for cloning efficiency in bovine somatic cells, direct comparison of cloning efficiency for mouse ES cells has not been studied.

The cell-cycle stages of donor cells [12] also influence cloning efficiency [13]. Donor cells at the $\mathrm{G}_{0} / \mathrm{G}_{1}$ phase synchronized by serum starvation or contact inhibition are used successfully for somatic cell cloning in farm animals [12]. Because synchronization of the cell cycle of ES cells to the $\mathrm{G}_{0} / \mathrm{G}_{1}$ phase by serum starvation or contact inhibition is difficult, however, ES cells at the M phase synchronized with nocodazole are used for nuclear transfer. Moreover, ES cells at the M phase have a higher rate of development into blastocysts than interphase nuclei, but the potential of nucleartransferred oocytes to develop into young is still low [10]. These and other technical differences might influence the extent of ES cell reprogramming in enucleated oocytes. The present study examined the effects of different nuclear transfer procedures, cell cycle stages and activation methods on cloning.

\section{Materials and Methods}

\section{Donor embryonic stem cells}

The TT2 ES cell line had a hybrid genetic background of C57BL/ $6 \times$ CBA and was used at passages 16 to 24 . ES cells were cultured on an inactivated embryonal fibroblast cell feeder layer [14] with Dulbecco's Modified Eagle's Medium modified for mouse ES cells (ES-DMEM) supplemented with $10 \%$ fetal bovine serum (FBS) and 1000 U leukaemia inhibitory factor (LIF, Gibco, Grand Island, N.Y.) [15] unless otherwise specified. ES cells were selected at random and karyotyped after treatment with $3 \mu \mathrm{g} / \mathrm{ml}$ nocodazole for $3 \mathrm{~h}$ using an air-dry method [16].

The cell cycle of ES cells was synchronized to the $\mathrm{M}$ phase before nuclear transfer by culture with 3 $\mu \mathrm{g} / \mathrm{ml}$ nocodazole (Aldrich Chemical Co., St Louis,
MO) for $3 \mathrm{~h}$ as previously reported [8]. To synchronize ES cells at the $\mathrm{G}_{1}$ phase, ES cell colonies were trypsinized and preplated on gelatin coated culture dishes for $30 \mathrm{~min}$ to remove the feeder cells. Small ES cells assumed to be in $\mathrm{G}_{1}$ phase were picked up [1]. When these small cells were cultured with bromodeoxyuridine (BrdU) for 0.5 and $1 \mathrm{~h}$, the incorporation rate was low (28 and $24 \%$ ) compared with randomly selected cells (40 and $49 \%$ ). The incorporation rate in both groups was $100 \%$ when ES cells were cultured for $12 \mathrm{~h}$.

\section{Nuclear transfer by fusion}

Chromosomes, at the second metaphase, of unfertilized oocytes recovered from superovulated F1 (C57BL $/ 6 \times \mathrm{C} 3 \mathrm{H})$ females, 14 to $16 \mathrm{~h}$ after injection of human chorionic gonadotropin, were removed mechanically and the enucleated oocytes were used as the recipient cytoplasm [8]. A single ES cell at the $M$ phase or the presumed $G_{1}$ phase was fused with enucleated oocytes using inactivated Sendai virus [8]. Fused oocytes were cultured in M16 [17] or modified potassium simplex optimized medium (KSOM-AA) [18] supplemented with $5 \mu \mathrm{g} / \mathrm{ml}$ cytochalasin B (CB, Aldrich Chemical Co., WI) for $1 \mathrm{~h}$ before activation.

\section{Nuclear transfer by direct injection}

All procedures were performed basically the same as previously reported $[1,19]$. The removal of maternal chromosomes and injection of the donor cell, whose membrane was broken beforehand, into recipient oocyte cytoplasm were performed using a piezo-electric actuated micromanipulator. The injected oocytes were cultured in KSOM-AA supplemented with $\mathrm{CB}$ for $1 \mathrm{~h}$ before activation.

\section{Oocyte activation and embryo culture}

Nuclear-transferred oocytes were cultured in Cafree M16 medium containing $10 \mathrm{mM}$ strontium with (for ES cells at the $G_{1}$ phase) or without $C B$ (for ES cells at the $M$ phase) for $5 \mathrm{~h}$, except for the study of the comparison of activation methods. Oocytes with a pronucleus(ei) without a second polar body for ES cells at the $G_{1}$ phase or oocytes with one pronucleus and a second polar body for ES cells at the $\mathrm{M}$ phase were considered to have diploid chromosome karyotypes and were cultured for 4 days in KSOM-AA in 5\% $\mathrm{CO}_{2}, 95 \%$ air at $37 \mathrm{C}$. To examine the chromosome composition of nucleartransferred oocytes, oocytes fused with ES cells at 
the M phases by HVJ were treated with $3 \mu \mathrm{g} / \mathrm{ml}$ nocodazole overnight and chromosome numbers were counted as shown above.

For comparison of the activation methods, oocytes fused with HVJ were activated with direct current pulses of $150 \mathrm{~V} / \mathrm{mm}$ for $50 \mu \mathrm{s}$, and two pulses of $50 \mathrm{~V} / \mathrm{mm}$ for $50 \mu$ s after a $20 \mathrm{~min}$ interval in Zimmermann cell fusion medium [8], then cultured in CB-supplemented KSOM-AA for $4 \mathrm{~h}$. Some electrically activated oocytes were cultured for $4 \mathrm{~h}$ in strontium and CB-supplemented medium, or were cultured for $1 \mathrm{~h}$ in the same medium following another $3 \mathrm{~h}$ culture in CBsupplemented KSOM-AA.

\section{Embryo transfer and histologic analysis of fetuses}

Blastocysts developed from nuclear-transferred oocytes were transferred to oviducts of day 0.5 or uteri of day 2.5 pseudopregnant ICR strain female mice. Cesarean section was performed on day 19.5 and live fetuses were raised by lactating foster mothers. Fetuses obtained on days 15.5 and 19.5 after transfer of nuclear-transferred oocytes fused with ES cells by HVJ were placed in formalin or Bouin's fixative solution. After fixation, the whole body was paraffin embedded, sectioned into $7 \mu \mathrm{m}$ thick sections, and stained with hemotoxylin and eosin, and histologic features were examined.

\section{Statistical analysis}

The data were analyzed using $\chi^{2}$-analysis.

\section{Results}

\section{ES cell characteristics}

When 10 to 15 ES cells were injected into blastocysts or 8-cell stage embryos and transferred to recipient mice, chimeras were obtained at a rate of $59 \%$.

The proportion of ES cells with a diploid karyotype $(2 \mathrm{n}=40)$ was $76 \%$. Of these, $10 \%(5 / 50)$ had tetraploid karyotypes $(2 n=80)$. Most nucleartransferred oocytes at the 1-cell stage had diploid karyotype constitution (87\%), and only one plate $(7 \%)$ had tetraploid karyotypes.

\section{Effects of different nuclear transfer methods and the donor cell cycle stages on cloning efficiency}

Table 1 shows the developmental potential of enucleated oocytes fused with ES cells by HVJ and direct injection. There were no significant differences between the proportions of enucleated oocytes that were fused with ES cells in the $\mathrm{G}_{1}$ phase and M-phase. The proportion of oocytes that survived after direct injection of ES cells at the $\mathrm{G}_{1}$ phase was significantly higher than that of ES cells at the M phase (69\% vs $41 \%)$. When ES cells at the $\mathrm{G}_{1}$ phase were used as donor cells, the potential of nuclear-transferred oocytes to develop into blastocysts was low both in the fusion $(2 \%)$ and direct injection (5\%) groups. When ES cells at the $M$ phase were used, the developmental potential of nuclear-transferred oocytes in the fusion group to the blastocyst stage was high $(67 \%)$ compared with the direct injection group (30\%). Although the in vitro developmental potential of nucleartransferred oocytes receiving ES cells was high, the proportions of blastocysts that developed into live offspring were low $(0-4 \%)$. A total of 6 live young were obtained, but all died soon after birth. Histologic analysis of the major organs, such as brain, spinal cord, mandibular gland, thymus, lung, liver, intestine, pancreas, kidney, testis, and bladder of fetuses on day 15.5 revealed abnormal histogenesis of the liver: failure of formation of liver lobules, congestion of the erythroblasts and erythrocytes, and focal parenchymal cell necrosis

Table 1. Developmental potential of oocytes having ES-cell nuclei

\begin{tabular}{|c|c|c|c|c|c|c|c|}
\hline \multirow[b]{2}{*}{ Introduced by } & \multirow[b]{2}{*}{ Cell cycle stage } & \multicolumn{4}{|c|}{ No. of oocytes } & \multicolumn{2}{|c|}{ No. of } \\
\hline & & fused & injected & cultured & $\begin{array}{l}\text { developed to } \\
\text { blastocysts } \\
\text { (transferred) }\end{array}$ & young & $\begin{array}{c}\text { placenta } \\
\text { only }\end{array}$ \\
\hline \multirow[t]{2}{*}{$\mathrm{HVJ}$} & $\mathrm{G}_{1}$ & $222 / 290(77)$ & - & 222 & $5(2)$ & 0 & 0 \\
\hline & $\mathrm{M}$ & $217 / 314(69)$ & - & 215 & $145(67)$ & $4(3)$ & $1(0.7)$ \\
\hline \multirow[t]{2}{*}{ injection } & $\mathrm{G}_{1}$ & - & $295 / 428(69)^{\mathrm{a}}$ & $28 \overline{6}$ & $14(5)$ & 0 & 0 \\
\hline & M & - & $206 / 502(41)^{\mathrm{b}}$ & 190 & $57(30)$ & $2(4)$ & $1(2)$ \\
\hline
\end{tabular}

a, b; $p<0.05$ 
Table 2. Developmental potential of oocytes fused with TT2 ES cells after activation with different methods

\begin{tabular}{lccccccc}
\hline $\begin{array}{l}\text { Activation } \\
\text { method }\end{array}$ & $\begin{array}{c}\text { No. of oocytes } \\
\text { fused/used } \\
(\%)\end{array}$ & $\begin{array}{c}\text { No. of oocytes } \\
\text { developed to } \\
\text { blastocysts } / \\
\text { cultured }(\%)\end{array}$ & $\begin{array}{c}\text { No. of } \\
\text { blastocysts } \\
\text { transferred }\end{array}$ & $\begin{array}{c}\text { No. of } \\
\text { dead } \\
\text { fetuses } \\
(\%)\end{array}$ & $\begin{array}{c}\text { No. of } \\
\text { live } \\
\text { young } \\
(\%)\end{array}$ & $\begin{array}{c}\text { No. of } \\
\text { placentas } \\
\text { only(\%) }\end{array}$ & $\begin{array}{c}\text { No. of } \\
\text { surviving } \\
\text { mice }\end{array}$ \\
\hline Electric & $84 / 84(100)$ & $40 / 77(52)^{\text {ac }}$ & 40 & $1(3)$ & $1(3)$ & 0 & 1 \\
SrCl2 & $198 / 210(94)$ & $122 / 198(62)^{\mathrm{c}}$ & 122 & 0 & $1(0.8)$ & $3(2)$ & 1 \\
Eletctric $\rightarrow \operatorname{SrCl} 21 \mathrm{~h}$ & $145 / 145(100)$ & $33 / 121(27)^{\mathrm{b}}$ & 33 & 0 & 0 & 0 & - \\
Eletctric $\rightarrow \operatorname{SrCl} 24 \mathrm{~h}$ & $108 / 108(100)$ & $47 / 108(44)^{\mathrm{a}}$ & 47 & 0 & 0 & 0 & - \\
\hline
\end{tabular}

$\mathrm{a}, \mathrm{b}, \mathrm{c}$ : Values in the same column with different superscripts are significantly different.

were detectable. Such liver abnormalities were also observed in the live young on day 19.5.

\section{Effect of different activation methods on cloning efficiency}

As shown in Table 2, there was no significant difference in the proportions of nuclear-transferred oocytes after activation with electric stimulation $(52 \%)$ and strontium treatment $(62 \%)$ that developed into blastocysts. After transfer of blastocysts to recipients, one live young was obtained in each group and both of the live young survived to adulthood. Development into blastocysts was decreased when both treatments were combined.

\section{Discussion}

Nuclear transferred oocytes receiving mouse ES cells have the potential to develop into fertile young. So far, two different nuclear-transfer procedures, direct injection and fusion, have been successfully used to produce ES-cell cloned mice. This is the first direct comparison of cloning efficiency using the same ES cell lines but different nuclear-transfer methods. The potential of nucleartransferred oocytes to develop into blastocysts was equally low ( 2 and $5 \%$, respectively) using both methods when ES cells at the presumed $\mathrm{G}_{1}$ phase were used. The potential into blastocyst stage was high, however, for the fusion method (67\%) compared with the injection method (30\%) when ES cells at the M phase were used. This same tendency was observed in our previous study $(42-88 \%$ for blastocysts) [3] using HVJ fusion, and in the report of Wakayama et al. [1] (14-44\% for morulae and blastocysts) using the piezo-electric actuated microinjection method. The efficiency of the production of cloned offspring, however, was low using both methods $(0-4 \%)$. The main differences between the two methods are the volume of donor cell cytoplasm incorporated into enucleated oocytes and the extent of nucleus exposure to the manipulation medium. For the fusion method, because a whole donor cell is fused with oocyte cytoplasm, all membrane and cytoplasmic material of the donor cell are incorporated into the enucleated oocytes, and the donor nucleus has little direct exposure to the medium environment. For the direct injection method, because the plasma membrane of donor cells is broken by the pipette and some cytoplasm of the donor cells flows out before nuclear transfer, the volume of cytoplasm incorporated into the oocytes is small compared with the fusion method. The chance of the donor nucleus to be exposed to the medium is high, however, which might lead to the low potential to develop into blastocysts.

The present study demonstrated that the potential of nuclear-transferred oocytes receiving ES cells at the M phase to develop into blastocysts is high as reported previously [8]. This is consistent with the report by Zhou et al. [10] who demonstrated that metaphase nuclei from ES cells have a significantly higher rate of development to the morula or blastocyst stage than do interphasic nuclei. ES cells are synchronized to the $\mathrm{M}$ phase by nocodazole treatment $[3,8]$, but synchronization to the $G_{0} / G_{1}$ phase is difficult to achieve by serum starvation or contact inhibition. A large population $(74 \%)$ of the small-size ES cells, presumed to be in the $\mathrm{G}_{1}$ phase, incubated with anti-BrdU antibody for 30 to $60 \mathrm{~min}$ were not positively stained, thus, contamination by $\mathrm{S}$ phase nuclei might have decreased the developmental potential of nucleartransferred oocytes [20]. The other possibility is that nuclei at the $\mathrm{M}$ phase have a better chance of 
being reprogrammed in enucleated MII oocytes than nuclei at the $G_{0} / G_{1}$ phase because chromosomes are directly exposed to unknown reprogramming factor(s) in the oocyte cytoplasm.

Kishikawa et al. [21] compared oocyte-activating agents for mouse cloning and demonstrated that the proportion of enucleated oocytes receiving cumulus cells by direct injection developing into morulae and blastocysts was significantly higher following strontium treatment than that following electric stimulation. The present study demonstrated that the developmental potential of enucleated oocytes fused with ES cells by HVJ was not different between electric stimulation and strontium treatment groups. In addition to differences in the nuclear transfer method and donor cell types, the most likely reason for such a discrepancy is the difference in the number of electric pulses given to nuclear-transferred oocytes, once in the report of Kishikawa et al. and three times in the present study, which might induce repeated $\mathrm{Ca}$ release. Combined treatment, however, decreased the potential of nucleartransferred oocytes to develop into blastocysts for unknown reasons.

\section{Acknowledgements}

The authors would like to thank Dr. T. Tokunaga for providing the TT2 embryonic stem cell line. This work was supported by grants 13308054 , 14034259, and 15039233 from the Ministry of Education, Culture, Sports, Science and Technology, Research Grant (13B-1) for Nervous and Mental Disorders from the Ministry of Health and Welfare, Ito Kinen Foundation, Nakajima International Interchange Foundation and the Program for Promotion of Basic Research Activities for Innovative Biosciences (PROBRAIN).

\section{References}

1. Wakayama T, Rodriguez I, Perry AC, Yanagimachi R, Mombaerts P. Mice cloned from embryonic stem cells. Proc Natl Acad Sci USA 1999; 96: 14984-14989.

2. Rideout WMIII, Wakayama T, Wutz A, Eggan K, Jackson-Grusby L, Dausman J, Yanagimachi R, Jaenisch R. Generation of mice from wild-type and targeted ES cells by nuclear cloning. Nat Genet 2000; 24: 109-110.

3. Amano T, Kato $\mathbf{Y}$, Tsunoda $\mathbf{Y}$. Full term development of enucleated mouse oocytes fused with embryonic stem cells from different cell lines. Reproduction 2001; 121: 729-733.

4. Rideout WMIII, Eggan K, Jaenisch R. Nuclear cloning and epigenetic reprogramming of the genome. Science 2001; 293: 1093-1098.

5. Humpherys D, Eggan $K$, Akutsu H, Hochedlinger K, Rideout WMIII, Biniszkiewicz D, Yanagimachi $\mathbf{R}$, Jaenisch R. Epigenetic instability in ES cells and cloned mice. Science 2001; 293: 95-97.

6. Eggan K, Akutsu H, Loring J, Jackson-Grusby L, Klemm M, Rideout WMIII, Yanagimachi R, Jaenisch R. Hybrid vigor, fetal overgrowth, and viability of mice derived by nuclear cloning and tetraploid embryo complementation. Proc Natl Acad Sci USA 2001; 98: 6209-6214.

7. Gao S, McGarry M, Ferrier T, Pallante B, Gasparrini B, Fletcher J, Harkness L, De Sousa P, McWhir J, Wilmut I. Effect of cell confluence on production of cloned mice using an inbred embryonic stem cell line. Biol Reprod 2003; 68: 595-
603.

8. Amano T, Tani T, Kato Y, Tsunoda Y. Mouse cloned from embryonic stem (ES) cells synchronized in metaphase with nocodazole. J Exp Zool 2001; 289: 139-145.

9. Ono $\mathbf{Y}$, Shimozawa N, Muguruma $K$, Kimoto $S$, Hioki K, Tachibana M, Shinkai Y, Ito M, Kono T. Production of cloned mice from embryonic stem cells arrested at metaphase. Reproduction 2001; 122: 731-736.

10. Zhou Q, Jouneau A, Brochard V, Adenot P, Renard JP. Developmental potential of mouse embryos reconstructed from metaphase embryonic stem cell nuclei. Biol Reprod 2001; 65: 412-419.

11. Galli C, Lagutina I, Vassiliev I, Duchi R, Lazzari G. Comparison of microinjection (piezo-electric) and cell fusion for nuclear transfer success with different cell types in cattle. Cloning Stem Cells 2002; 4: 189196.

12. Tsunoda Y, Kato Y. Recent progress and problems in animal cloning. Differentiation 2002; 69: 158-161.

13. Campbell KHS, Loi P, Otaegui PJ, Wilmut I. Cell cycle co-ordination in embryo cloning by nuclear transfer. Rev Reprod 1996; 1: 40-46.

14. Tokunaga T, Tsunoda Y. Efficacious production of viable germline chimeras between embryonic stem (ES) cells and 8-cell stage embryos. Develop Growth $\mathcal{E}$ Differ 1992; 34: 561-566.

15. Robertson EJ. Embryo-derived stem cell lines. In: Robertson EJ (ed.), Teratocarcinomas and 
Embryonic Stem Cells. Oxford: IRL Press; 1987: 71112.

16. Tarkowski AK. An air-drying method for chromosome preparation from mouse eggs. Cytogenetics 1966; 5: 394-400.

17. Whittingham DG. Culture of mouse ova. J Reprod Fertil Suppl 1971; 14: 7-21.

18. Ho Y, Wigglesworth K, Eppig JJ, Schultz RM. Preimplantation development of mouse embryos in KSOM: Augmentation by amino acids and analysis of gene expression. Mol Reprod Dev 1995; 41: 232238.
19. Wakayama T, Perry AC, Zuccotti M, Johnson KR, Yanagimachi R. Full-term development of mice from enucleated oocytes injected with cumulus cell nuclei. Nature 1998; 394: 369-374.

20. Tani T, Kato Y, Tsunoda Y. Direct exposure of chromosomes to nonactivated ovum cytoplasm is effective for bovine somatic cell nucleus reprogramming. Biol Reprod 2001; 64: 324-330.

21. Kishikawa H, Wakayama T, Yanagimachi $R$. Comparison of oocyte-activating agents for mouse cloning. Cloning 1999; 1: 153-159. 